\title{
Seasonal variation in the lower thermotolerance of adult New Zealand flower thrips Thrips obscuratus (Crawford)
}

\author{
G.F. McLaren ${ }^{1,2}$, K.M. Colhoun ${ }^{1}$ and R.C Butler ${ }^{3}$ \\ ${ }^{1}$ The New Zealand Institute for Plant \& Food Research Limited, Clyde, 990 Earnscleugh \\ Road, R.D.1, Alexandra 9391, New Zealand \\ ${ }^{2}$ Current address: 53 Paterson Rd, RD2 Cromwell 9384, New Zealand \\ ${ }^{3}$ The New Zealand Institute for Plant E Food Research Limited, Private Bag 4704, \\ Christchurch, New Zealand \\ Corresponding authors: kcolhoun@plantandfood.co.nz and jillandjohn@xtra.co.nz
}

\begin{abstract}
The ability of New Zealand flower thrips (NZFT) to tolerate cold temperatures was investigated. Thrips were collected from a range of natural sources in Central Otago over 2 years. Some adult NZFT (predominantly females) survived for up to 2 months on peach fruit at $0-1{ }^{\circ} \mathrm{C} ; \mathrm{LT}_{50}=35.4$ days and $\mathrm{LT}_{99}=70.7$ days. Plant material containing NZFT was exposed for $24 \mathrm{~h}$ to $-10,-7.5,-5,-2.5$ and $0^{\circ} \mathrm{C}$ and NZFT mortality measured. Irrespective of the time of year when NZFT were collected, mortality was similar after $24 \mathrm{~h}$ at $-2.5^{\circ} \mathrm{C}$ to that at $0^{\circ} \mathrm{C}$ (means $=4.6,4.7 \%$ ), but increased with decreasing temperature (mean mortality $=22.5 \%$ at $-5^{\circ} \mathrm{C}, 66.3 \%$ at $-7.5^{\circ} \mathrm{C}$ and $82.0 \%$ at $-10^{\circ} \mathrm{C}$ ). From $-7.5^{\circ} \mathrm{C}$ downwards, responses to changes in temperature varied between seasons $(\mathrm{P}<0.01)$, with autumn adults being less cold-tolerant than those collected in spring. Central Otago winter temperatures would not have threatened the survival of NZFT over the study period.
\end{abstract}

Keywords New Zealand flower thrips, Thrips obscuratus, cold tolerance, stonefruit, gorse, seasonal effects.

\section{INTRODUCTION}

The cold hardiness of an insect is generally considered an important determinant of its distribution, affecting its ability to survive winter and spring conditions (Goto \& Kimara 1998; Addio-Bediako et al. 2000; Sinclair \& Roberts 2005). Some insect species overwinter as a particular life stage, sometimes in diapause, while others retain cold tolerance all year round, irrespective of stage, as in the case of at least two New Zealand alpine insects (Sinclair 1997; Ramlov et al. 1992).
The mechanisms involved in adaptation to cold conditions appear to differ between insect species, with diverse explanations being offered, including removal of ice nucleators from the gut and body to facilitate supercooling, induction of carbohydrate cryoprotectants, antifreeze proteins, gut-clearing, membrane changes and actual freezing of body liquids (Chen \& Walker 1993). Cold tolerance in Drosophila species has been associated with the formation of heat-shock proteins (Hsp70) that 
confer resistance to heat as well as cold (Goto \& Kimura 1998; Neven 1999; Hoffman et al. 2003; Sejerkilde et al. 2003).

New Zealand flower thrips (Thrips obscuratus (Crawford)) (NZFT) is possibly unique among New Zealand insects in that it is highly multivoltine and under Central Otago conditions completes at least seven generations in a year, with each generation taking 4-6 weeks during the growing season for temperate fruit crops. The upper thermotolerance limit of adult NZFT varies according to the season and is higher in autumn than spring (McLaren \& Fraser 1998). In the current study, the aim was to investigate the cold tolerance of NZFT populations throughout the year, especially in relation to their ability to survive both Central Otago's winter and coolstorage of fruit in summer and autumn.

\section{METHODS}

\section{Survival in cool-storage}

Trays of 'Redhaven' peaches were picked from trees growing at Clyde Research Centre on 8 February 2001 and packed into six single-layered cardboard trays, each containing 23 fruit in pocket packs. The trays were held on shelves in a coolstore at $0-1^{\circ} \mathrm{C}$. One tray was removed after each of 1, 15, 33, 47, 56 and 63 days and held at $20^{\circ} \mathrm{C}$ for $3-15 \mathrm{~h}$. Each fruit was inspected and the numbers of live or dead NZFT on the fruit and inside the tray were recorded. Confirmation of their state sometimes required a nudge with a needle under a binocular microscope. The trial was terminated after 9 weeks, as many of the fruit had collapsed or become decayed.

\section{Seasonal cold tolerance}

From September 2006 to July 2008, samples of NZFT were collected from host plants within $4 \mathrm{~km}$ of Clyde Research Centre at approximately monthly intervals and placed inside plastic containers $(34 \times 12 \times 12 \mathrm{~cm})$ (Table 1). Each tightly-sealed container contained a rack at the base that prevented thrips from being trapped

Table 1 Total numbers of adult New Zealand flower thrips (NZFT) collected from various host plants, tested at different temperatures on specific dates and seasons.

\begin{tabular}{|c|c|c|c|c|c|c|c|c|c|}
\hline \multirow[t]{2}{*}{ Year } & \multirow[t]{2}{*}{ Season } & \multirow{2}{*}{$\begin{array}{l}\text { Host } \\
\text { plant }\end{array}$} & \multirow{2}{*}{$\begin{array}{l}\text { Sampling dates } \\
\text { (day/month) }\end{array}$} & \multicolumn{6}{|c|}{ temperature $\left({ }^{\circ} \mathrm{C}\right)$} \\
\hline & & & & -10 & -7.5 & -5 & -2.5 & 0 & 20 \\
\hline \multirow[t]{4}{*}{2006} & \multirow[t]{4}{*}{ spring } & gorse & $13 / 9$ & 184 & 209 & 145 & 65 & 78 & 110 \\
\hline & & peony & $20 / 12$ & 71 & 280 & 408 & 272 & 151 & 67 \\
\hline & & cherry & $26 / 9$ & 14 & 17 & 28 & 39 & 27 & 25 \\
\hline & & hawthorn & $24 / 10$ & 18 & 11 & 7 & 13 & 24 & 18 \\
\hline $2006 / 07$ & summer & apricot & $14 / 2$ & 32 & 30 & 25 & 27 & 99 & 129 \\
\hline \multirow[t]{4}{*}{2007} & autumn & nectarine & $6 / 3$ & 12 & 48 & 18 & 15 & 68 & 51 \\
\hline & winter & gorse & $9,30 / 7$ & 3 & 1 & 2 & $\star 1$ & 2 & 1 \\
\hline & spring & gorse & $03 / 9 ; 1,22 / 10$ & 228 & 302 & 198 & 186 & 323 & 338 \\
\hline & & broom & $20 / 11$ & 124 & 148 & 73 & 48 & 128 & 136 \\
\hline \multirow[t]{3}{*}{$2007 / 08$} & summer & broom & $13 / 12$ & * & * & 6 & 27 & * & 10 \\
\hline & & peony & $13 / 12$ & 169 & 341 & 90 & 313 & 138 & 214 \\
\hline & & apricot & $21 / 1 ; 11 / 2$ & 193 & 98 & 288 & 147 & 553 & 142 \\
\hline \multirow[t]{3}{*}{2008} & autumn & gorse & $08 / 5$ & * & * & * & 2 & * & * \\
\hline & & peach & $17 / 3 ; 2 / 4$ & 91 & 79 & 99 & 103 & 189 & 184 \\
\hline & winter & gorse & $\begin{array}{l}9,23,24,26,30 / 6 ; \\
23,24,27 / 7\end{array}$ & 168 & 118 & 77 & 26 & 49 & 146 \\
\hline
\end{tabular}

\footnotetext{
${ }^{1 *}=$ not analysed (too few thrips).
} 
in moisture. Samples of ripe fruit were placed in 5 litre plastic containers with a tight-fitting plastic lid; the lid included cloth-covered ventilation holes in 2007 but not in 2008. On most sampling occasions, one container was placed in an incubator set at $20,0,-2.5,-5,-7.5$ or $-10^{\circ} \mathrm{C}$ for $24 \mathrm{~h}$, and then removed and held at ambient temperature for 3-4 h. All the plant material and its containers were then inspected and the numbers of live and dead NZFT recorded. Samples were generally collected over three consecutive days because of limited incubator availability; samples were tested at 0 and $20^{\circ} \mathrm{C}$ on each day. No measurement was made of natural mortality when the sample first arrived at the laboratory, but mortality of samples held at $20^{\circ} \mathrm{C}$ was expected to provide an approximation of likely losses during collection and transportation to the laboratory. It was assumed that these mortalities would have been typical of those occurring across all treatments prior to the commencement of the experiment.

All the adults found on gorse over winter and early spring were female. A few males were found on fruit in summer and autumn, but were not recorded separately. McLaren (1992) documented the absence of male NZFT in early spring and the continued predominance of females in late spring; observations of NZFT on fruit in Central Otago over a number of years have indicated that males represent fewer than $10 \%$ of the adult population (G.F. McLaren, unpublished data). Some larvae were found on gorse in October 2007 and one in June 2008. Therefore analyses were conducted on numbers of adults (predominantly females).

\section{Statistical analyses}

\section{Survival in cool-storage}

The number of dead thrips out of the total thrips recovered per sample in cool-storage was analysed with a binomial generalized linear model with a complementary log-log link (McCullagh \& Nelder 1989). First, the mean mortality figures for NZFT from all sampling dates and at each storage time were analysed. A day-response relationship was then fitted to the means, similar to Probit Analysis (Finney 1971), with $\ln$ (Days) as the predictor: $\%=100\left[1-\exp \left(-\left(\frac{D a y s}{M}\right)^{-b}\right)\right]$

This curve has a predicted mortality of $0 \%$ at Day $0 . M$ is the mortality at the inflection point of the curve, and $b$ is a slope parameter. The curve was fitted using GenStat's PROBITANALYSIS procedure, and assessed for fit to the means. The numbers of days to give 50, 90 or $99 \%$ mortality $\left(\mathrm{LT}_{50}, \mathrm{LT}_{90}, \mathrm{LT}_{99}\right)$ were estimated from the fitted curve using GenStat's FIELLER procedure (GenStat Committee 2009a), which provides 95\% confidence limits for the $\mathrm{LT}_{\%}$ estimates.

\section{Seasonal cold tolerance}

The total number of dead thrips out of the total thrips found in each container was analysed to assess percentage mortality. The data were analysed using a binomial generalized linear model with a logit link (McCullagh \& Nelder 1989), allowing for over-dispersion (i.e. container to container variation). In these analyses, the impacts of collection season and treatment temperature on mortality were assessed, along with the interaction between them, using F-tests. Estimated mean mortality for each season and treatment temperature and the associated 95\% confidence limits were obtained on the transformed (logit) scale, and back-transformed to percentages.

Temperature response relationships in the means were investigated for a subset of the data (see Results below). A logistic response curve of $\log$ (-Temperature) was fitted to the means using a binomial generalized non-linear model approach, as implemented in GenStat's PROBITANALYSIS procedure (GenStat Committee 2009a):

$$
\% \text { Mortality }=P_{0}+\frac{100-P_{0}}{1+\left(\frac{- \text { Temperature }}{-\mathrm{D}_{50}}\right)^{-b}}
$$

This curve assumes that a sufficiently low temperature will give $100 \%$ mortality for all seasons. $P_{0}$ is the estimated mortality at $0^{\circ}, \mathrm{D}_{50}$ 
is the temperature giving a mortality half way between $P_{0}$ and $100 \%$ mortality, and $b$ is related to the slope of the curve at Temperature $=D_{50}$. The curve was fitted allowing for each of the three parameters to be the same across seasons, or to vary between seasons. Estimates for temperatures to give mortalities of 90 or $99 \%$ of those not dying at $0^{\circ} \mathrm{C}\left(\mathrm{D}_{90}, \mathrm{D}_{99}\right)$ were calculated from the fitted parameters using GenStat's FIELLER procedure, as for the cool-storage data. All analyses were carried out using GenStat (GenStat Committee 2009b).

\section{RESULTS}

\section{Survival in cool-storage}

Estimated mean mortality for the number of days in cool-storage showed that mortality at Day 1 was higher than that for Day 15. Further analysis of the data suggested that the results for Day 1 deviated from the general trend of the other dates, and Day 1 was therefore excluded from the analysis (Figure 1). The estimated lethal time $\left(\mathrm{LT}_{\%}\right)$ in days for 50, 90 and $99 \%$ mortality showed that NZFT can survive for relatively long periods in cool-storage, with at least 50\% surviving for more than 1 month and a few up to 2 months (Table 2). In fact, some NZFT outlived their fruit hosts.

Table 2 Time (days) to give 50, 90 or $99 \%$ mortality (95\% confidence limits) of New Zealand flower thrips on peaches.

\begin{tabular}{ll}
\hline$\%$ mortality & Days at $0-1^{\circ} \mathrm{C}$ \\
\hline 50 & $35.4(30.2,39.5)$ \\
90 & $54.9(49.2,64.3)$ \\
99 & $70.7(61.1,91.0)$ \\
\hline
\end{tabular}

\section{Seasonal cold tolerance}

Therewas a significant interaction between season and temperature $(\mathrm{P}<0.001)$ indicating that the mortality-temperature response patterns varied substantially between sampling seasons (Table 3 ). The interaction is due in part to the varying patterns of change in mortality between 0 and $20^{\circ} \mathrm{C}$, varying from a small decrease to a large increase (autumn 2008). Mortality at $20^{\circ} \mathrm{C}$ gives some indication of natural mortality, which was very low among winter- and spring-collected thrips (average mortality $=0.5-3.4 \%$ ), but much higher amongst those collected on fruit in summer and autumn (Table 3). Mortality on fruit at $20^{\circ} \mathrm{C}$ was highest in autumn 2008. Some of these losses were later demonstrated to be associated with the absence of ventilation in the containers used for fruit. Therefore, temperature-response patterns were further explored after excluding the $20^{\circ} \mathrm{C}$ data.

For the $\leq 0^{\circ} \mathrm{C}$ only data, the season $\times$ temperature interaction was significant $(\mathrm{P}=0.009)$, indicating that the shape of the temperature response varied between the seasons (Figure 2) even after exclusion of the $20^{\circ} \mathrm{C}$ data. For all seasons, mean mortality decreased as $24-\mathrm{h}$ treatment temperatures increased from $-10^{\circ} \mathrm{C}$ to $0^{\circ} \mathrm{C}$. However, mortality at $-10^{\circ} \mathrm{C}$, and the rates of decline in mortality varied considerably between seasons (Figure 2).

Logistic curves fitted to the $\leq 0^{\circ} \mathrm{C}$ data only allowed these differences in response to be summarised (Figure 2, Table 4). Both the $P_{0}$ and $\mathrm{D}_{50}$ parameters varied significantly between

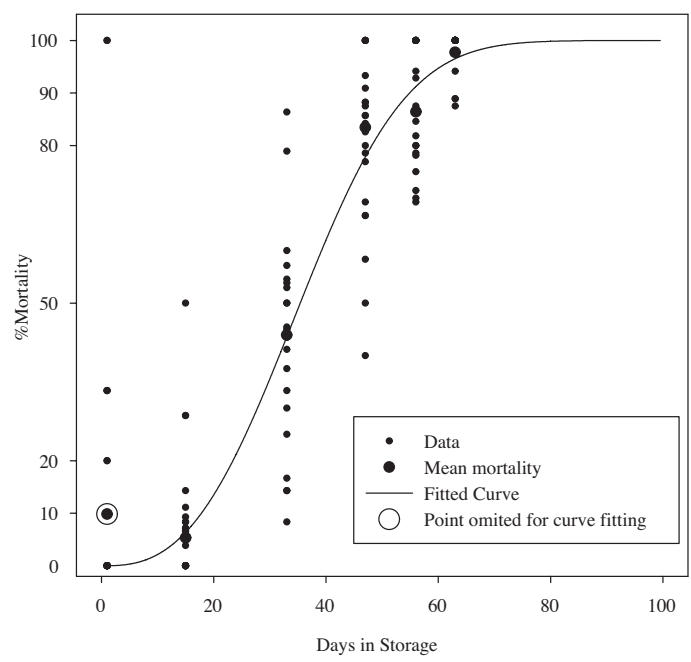

Figure 1 Mortality of New Zealand flower thrips through time in cool-storage, showing mean mortality, mortality on individual fruits and the fitted complementary-log-log timeresponse curve. 
Table 3 Estimated percentage mortality for New Zealand flower thrips collected in seven different seasons when subjected to $24 \mathrm{~h}$ at six different temperatures ( $95 \%$ confidence limits in brackets).

\begin{tabular}{lcccccc}
\hline Season & $-10^{\circ} \mathrm{C}$ & $-7.5^{\circ} \mathrm{C}$ & $-5^{\circ} \mathrm{C}$ & $-2.5^{\circ} \mathrm{C}$ & $0{ }^{\circ} \mathrm{C}$ & $20^{\circ} \mathrm{C}$ \\
\hline \multirow{2}{*}{2006 spring } & 95.1 & 97.3 & 34.7 & 3.9 & 2.1 & 0.5 \\
& $(75.4,99.2)$ & $(85.3,99.6)$ & $(22.8,48.8)$ & $(0.7,19.2)$ & $(0.1,26.2)$ & $(0.0,79.8)$ \\
$06 / 07$ summer & 96.9 & 76.7 & 56.0 & 44.4 & 47.5 & 18.6 \\
& $(3.2,100.0)$ & $(15.1,98.4)$ & $(7.7,95.1)$ & $(5.5,91.6)$ & $(18.9,77.9)$ & $(4.7,51.3)$ \\
2007 autumn & 99.9 & 95.8 & 44.4 & 26.7 & 27.9 & 25.5 \\
& $(0.0,100.0)$ & $(14.9,100.0)$ & $(3.2,95.2)$ & $(0.7,94.9)$ & $(5.9,70.6)$ & $(3.8,75.0)$ \\
2007 spring & 72.2 & 29.6 & 15.9 & 2.6 & 1.1 & 1.7 \\
& $(53.7,85.3)$ & $(17.3,45.7)$ & $(5.8,36.7)$ & $(0.2,30.0)$ & $(0.1,18.9)$ & $(0.2,16.0)$ \\
$07 / 08$ summer & 71.8 & 54.9 & 16.7 & 2.9 & 8.0 & 21.0 \\
& $(53.7,84.9)$ & $(38.9,69.9)$ & $(7.4,33.5)$ & $(0.5,15.6)$ & $(3.2,18.3)$ & $(10.1,38.8)$ \\
2008 autumn & 49.5 & 39.2 & 31.3 & 24.8 & 30.2 & 92.9 \\
& $(19.2,80.1)$ & $(12.0,75.4)$ & $(9.5,66.3)$ & $(6.7,60.2)$ & $(12.9,55.7)$ & $(65.4,98.9)$ \\
2008 winter & 35.7 & 9.3 & 11.7 & 11.5 & 8.2 & 3.4 \\
& $(15.8,62.2)$ & $(1.2,46.6)$ & $(1.2,59.2)$ & $(0.2,89.2)$ & $(0.3,75.1)$ & $(0.2,43.4)$ \\
\hline
\end{tabular}

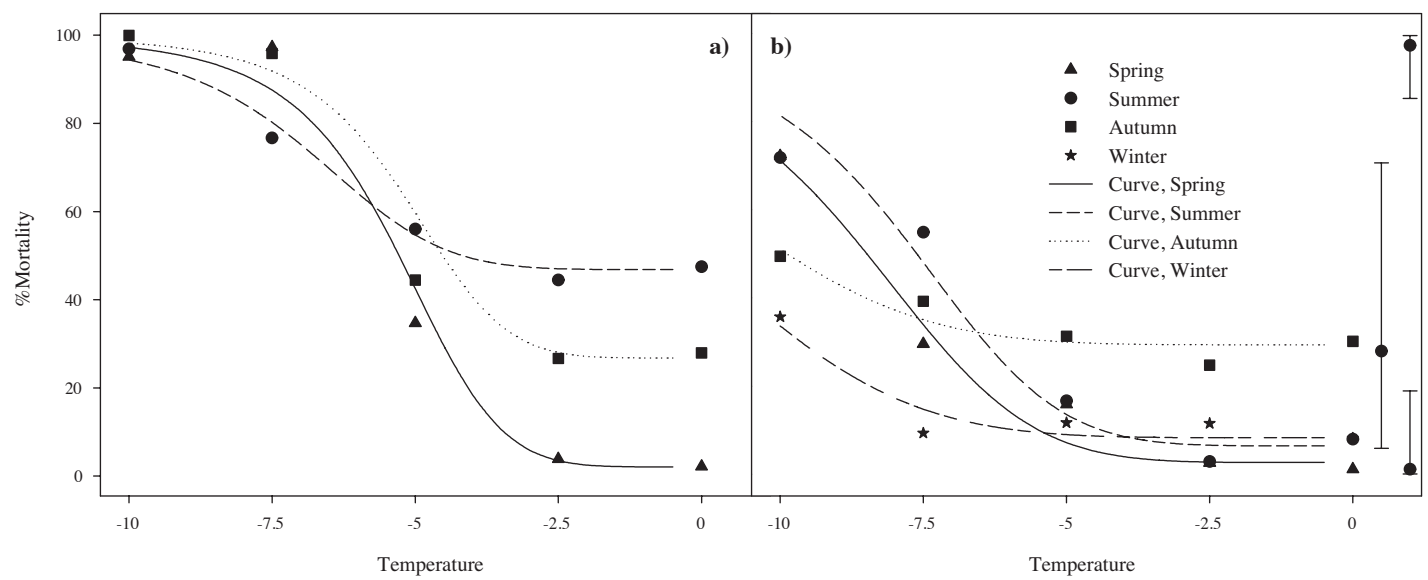

Figure 2 Mean percentage mortality and fitted logistic dose-response curves for New Zealand flower thrips for temperatures $\leq 0^{\circ} \mathrm{C}$. (a) data for spring, summer and autumn during 2006/07 (b) data for spring, summer, autumn and winter during 2007/08. Error bars are 95\% confidence limits for the smallest, largest and a mid-range mean. For clarity, these are drawn to one side rather than at the mean; other confidence limits are omitted for clarity (see Table 3).

seasons $(\mathrm{P}<0.001$, Table 4$)$, but the slope parameter $b$ did not, indicating some consistency in the rate of decline of mortality. Mortality at $0^{\circ} \mathrm{C}\left(P_{0}\right)$ was much higher for thrips collected in 2006/07 summer, 2007 autumn and 2008 autumn than for the other four seasons. The temperatures required to reduce mortality by a further $50 \%\left(\mathrm{D}_{50}\right)$ also varied substantially between the seasons, from $-5.2^{\circ} \mathrm{C}(2007$ autumn $)$ to $-11.9^{\circ} \mathrm{C}$ (2008 winter). Temperatures required 
for further reductions $\left(D_{90}, D_{99}\right)$ varied similarly and included some very low temperatures, but only one estimate $\left(\mathrm{D}_{99}\right.$, winter 2008$)$ was as cold as that of a freezer $\left(-18^{\circ} \mathrm{C}\right)$, at which temperature fewer than $1 \%$ would survive.

Of the summer 2006/07 population of NZFT, $46.8 \%$ would have been killed after $24 \mathrm{~h}$ at $0^{\circ} \mathrm{C}$ and $50 \%$ of the remainder would have been killed by $24-\mathrm{h}$ treatment at $-6.8^{\circ} \mathrm{C}$. The autumn populations of both 2007 and 2008 were also sensitive to $0^{\circ} \mathrm{C}(26.8 \%$ and $29.4 \%$ mortality respectively), with $50 \%$ of the remaining individuals being vulnerable to a further drop to $-5.2^{\circ} \mathrm{C}$ in 2007 and a remarkable $-11.6^{\circ} \mathrm{C}$ in 2008 . The majority of the winter 2008 population that survived $0^{\circ} \mathrm{C}$ could tolerate temperatures as low as $-11.9^{\circ} \mathrm{C}$. The spring populations in both 2006 and 2007 had the highest tolerance to $0^{\circ} \mathrm{C}$. Overall, winter and spring populations had the highest cold tolerance and autumn populations the lowest.

\section{DISCUSSION}

Adult NZFT survived on peaches for long periods in cool-storage and could possibly have lived longer if their fruit hosts had survived as well. There seemed to be an initial time in which the thrips adjusted to cold $\left(0^{\circ} \mathrm{C}\right)$ conditions since mortality after just 1 day was higher than that after 15 days. For instance, it was noted that the thrips had moved from their initial positions scattered all over the fruit on Day 1, to all being underneath the fruit on Day 15. When the fruit were removed from the cool-store after 15 or more days, all the thrips were immobile, but many recovered within a few hours, after they had been warmed. Their ability to reproduce following cool-storage was not investigated.

Numbers of NZFT in Central Otago decline naturally in the autumn and remain at very low levels over winter. McLaren \& Alspach (2006) suggested that this decline could be a consequence of a slowing of plant growth in autumn, with diminishing supplies of fresh growing tips and flowers that provide pollen, limiting opportunities for oviposition and development. The situation is compounded in winter since the majority of NZFT's hosts are deciduous. Gorse (Ulex europeaus) is one of just two host plants, both of which are evergreen, that have been recorded as overwintering host for NZFT; the other is Verbascum thapsus. While it is possible that the NZFT populations on gorse were supplemented by new arrivals from Canterbury in late winter, some probably survived the whole winter on gorse (McLaren et al. 2010). In the

Table 4 Parameters estimated from fitting logistic dose-response curves to data for New Zealand flower thrips over seven seasons, for temperatures $\leq 0^{\circ} \mathrm{C}(95 \%$ confidence limits or SE in brackets).

\begin{tabular}{lcccc}
\hline & $\begin{array}{c}\% \text { mortality } \\
\text { at } 0^{\circ} \mathrm{C}\end{array}$ & \multicolumn{4}{c}{$\begin{array}{c}\text { Temperature }\left({ }^{\circ} \mathrm{C}\right) \text { producing } 50,90 \text { or } 99 \% \text { mortality } \\
\text { of those that did not die at } 0^{\circ} \mathrm{C}\end{array}$} \\
\hline Season & $P_{0}$ & $\mathrm{D}_{50}$ & $\mathrm{D}_{90}$ & $\mathrm{D}_{99}$ \\
\hline 2006 spring & $2.1(2.4)$ & $-5.3(-4.8,-5.9)$ & $-6.7(-6.0,-7.7)$ & $-8.1(-7.1,-9.8)$ \\
$2006 / 07$ summer & $46.8(15.6)$ & $-6.8(-3.5,-12.9)$ & $-8.6(-4.5,-16.5)$ & $-10.3(-5.5,-20.4)$ \\
2007 autumn & $26.8(18.0)$ & $-5.2(-2.8,-9.3)$ & $-6.5(-3.6,-11.8)$ & $-7.8(-4.4,-14.6)$ \\
2007 spring & $2.7(2.4)$ & $-8.6(-7.6,-9.7)$ & $-10.8(-9.6,-12.7)$ & $-13.0(-11.2,-16.3)$ \\
$2007 / 08$ summer & $6.4(2.7)$ & $-7.8(-7.0,-8.7)$ & $-9.8(-8.8,-11.3)$ & $-11.8(-10.4,-14.4)$ \\
2008 autumn & $29.4(8.2)$ & $-11.6(-7.2,-19.1)$ & $-14.5(-9.2,-24.8)$ & $-17.5(-11.1,-31.0)$ \\
2008 winter & $8.3(7.8)$ & $-11.9(-8.8,-16.5)$ & $-14.9(-11.1,-21.6)$ & $-18.0(-13.3,-27.2)$ \\
$b^{*}$, proportional to & & $5.618(0.843)$ & & \\
slope of curve at $\mathrm{D}_{50}$ & & & & \\
\hline
\end{tabular}


current study, just one NZFT larva was recorded on gorse flowers in June 2008; none was found in the other winter months, suggesting that any development that occurs in Central Otago's winter is very limited. Meteorological records from Clyde Research Centre showed that in the winters of 2007 and 2008, the lowest temperatures were $-8.0^{\circ} \mathrm{C}$ on both 28 June and 22 July 2007 and $-5.5^{\circ} \mathrm{C}$ on 9 July 2008 . On the evidence presented in Table 4, these winter temperatures seem unlikely to kill all the NZFT population in Central Otago.

If temperature tolerance is associated with the production of cold or heat-shock proteins, these could have a dual effect, providing protection against both heat and cold in summer and winter (Sejerkilde et al. 2003). Therefore, over the course of a year, both winter and summer populations should be able to withstand low temperatures. Previous research showed that NZFT was more heat-tolerant in autumn than in spring (McLaren \& Fraser 1998). The current research showed that the autumn population was less coldtolerant than the spring population, indicating a general upward shift in the range of temperature tolerance (upper and lower together) from spring to autumn. The mechanism involved in this shift was not investigated but suggests that there is some underlying conditioning that confers greater heat tolerance in generations that have recently experienced high temperatures (i.e. autumn populations) and greater cold tolerance in those spring populations that have just experienced winter conditioning.

The cold tolerance of adult NZFT appeared to be higher in winter and spring than in autumn, but it was also apparent that there were some individuals that were highly cold-tolerant in every season and could certainly survive the low temperatures of Central Otago winters, as well as long exposures in cool-storage. The results indicate there is diversity in temperature tolerance within any population of NZFT.

\section{REFERENCES}

Addio-Bediako A, Chown SL, Gaston KJ 2000. Thermal tolerance, climatic variability and latitude. Proceeding of the Royal Society of London, B 267: 739-745.

Chen C-P, Walker VK. 1993. Increase in coldshock tolerance by selection of cold resistant lines in Drosophila melanogaster. Ecological Entomology 18: 184-190.

Finney DJ 1971. Probit Analysis. Cambridge University Press, Cambridge, UK. 333 p.

GenStat Committee. 2009a. GenStat Reference Manual, release 12 - Part 3, Procedure Library PL20. VSN International, Oxford, UK.

GenStat Committee. 2009b. The Guide to GenStat Release 12 - Parts 1-3. VSN International, Oxford, UK.

Goto SG, Kimura MT 1998. Heat- and coldshock responses and temperature adaptations in subtropical and temperate species of Drosophila. Journal of Insect Physiology 44:1233-1239.

Hoffman AA, Sorenson JG, Loeschcke V 2003. Adaptation of Drosophila to temperature extremes: bringing together quantitative and molecular approaches. Journal of Thermal Biology 28: 175-216.

McCullagh P, Nelder JA 1989. Generalized Linear Models. Chapman \& Hall, London. $511+x i x$ pp.

McLaren GF 1992. Thrips on nectarines in the spring. Proceedings of the 45th New Zealand Plant Protection Conference: 111-115.

McLaren GF Alspach PA 2006. Incidence of New Zealand flower thrips in stonefruit orchards, between flowering and harvest. New Zealand Plant Protection 59: 63-68.

McLaren GF, Fraser JA 1998. Upper thermotolerance of New Zealand flower thrips Thrips obscuratus (Crawford). Proceedings of the 51st New Zealand Plant Protection Conference: 204 - 210.

McLaren GF, Reid S, Colhoun KM 2010. Long-distance movement of New Zealand flower thrips (Thrips obscuratus Crawford) (Thysanoptera: Thripidae) into Central Otago orchards. New Zealand Entomologist 33: 5-13.

Neven L 1999. Cold hardiness adaptations of codling moth, Cydia pomonella. Cryobiology 38: 43-50. 
Ramlov H, Bedford J, Leader J 1992. Freezing tolerance of the New Zealand alpine weta, Hemideina maori Hutton [Orthoptera; Stenopelmatidae]. Journal of Thermal Biology 17: 51-54.

Sejerkilde M, Sorenson JG, Loeschcke V 2003. Effects of cold- and heat hardening on thermal resistance in Drosophila melanogaster. Journal of Insect Physiology 49: 719-726.
Sinclair BJ 1997. Seasonal variation in freezing tolerance of the New Zealand alpine cockroach Celatoblatta quinquemaculata. Ecological Entomology 22: 462-467.

Sinclair BJ, Roberts SP 2005. Acclimation, shock and hardening in the cold. Journal of Thermal Biology 30: 557-562. 